\title{
Hackers, Makers, and Crowd Funding: Lowering the Barriers to Entrepreneurship
}

\author{
Howard E. Aldrich (University of North Carolina at Chapel Hill)
}

\section{KEYWORDS: Social Media \& Networks, Entrepreneurship, Innovation, Information Technology, Product Development, Strategy, Crowdfunding for small business.}

Not too long ago, hackers were engineers with a propensity for mischief and anarchy; makers tinkered with hand tools in their basements; and crowdfunding required nothing more than a guitar, a hat and a public park. But today, all three phenomena are profoundly reshaping innovation and entrepreneurship, and allowing more ideas to be developed and tested in the marketplace more quickly. Here is an overview of all three and their collective impact, along with some questions to consider.

\section{Hackers}

Historically in the information technology industry, hackers were software engineers and coders who hacked into computer programs and altered them, sometimes for their own benefit but often to do something for a group they identified with -- typically some kind of collective (Gershenfeld 2005). Commonly, their reward was simply earning higher status within their group, rather than anything material, although some hackers "went over to the dark side" and put their skill to criminal use. In the past decade, the term "hacker" has been extended to include people who take off-the-shelf hardware products, manufactured by others, and try to figure out ways to either improve them or do something other than the original intended purpose (Anderson 2012).

\section{Makers}

The term "maker" is a more inclusive concept, referring not only to people who alter the work of others but also those who produce original work, conceptualizing and executing a project of their own design. Many makers use hand tools such as hammers, screw drivers and saws, but the term also includes people who use powerassisted tools, such as computer numerically controlled (CNC) machines and 3-D printers (Lang 2013).
The maker movement, which stresses new, inventive, and unique applications of technologies, has a strong focus on learning and using practical skills creatively.

Makers once worked in their own workspaces such as basements, garages, and sheds. Beginning in the mid-2000s, however -- spurred on by early champions of handcrafted products, local autonomy and the social benefits of making as opposed to buying -- "maker spaces" began emerging around the world (Gershenfeld 2005). These cooperatively organized spaces, usually funded by donations and user fees, were equipped with a wide variety of tools that many makers could not afford on their own. Subsequently the maker movement and its associated maker spaces have brought highquality craft work within reach of thousands, if not millions, of people.

With its accompanying technological and institutional changes, the maker movement has been likened to a second Industrial Revolution. In less grandiose terms, it has been deemed as important as the rise of the commercial Internet in the 1990s. Based upon my presentation at Center for Research on Small Business and Entrepreneurship (Aldrich, 2013), I argue that the maker movement has made user-driven innovation and bottom-up entrepreneurship easier.

\section{Crowdfunding}

As the roles of hackers and makers have evolved, the emergence of crowdfunding has given small-scale entrepreneurs an alternative to the usual funding channels such as banks and angel investors. Technological and institutional changes in the past decade have substantially lowered the barriers for entrepreneurs wishing to start their own businesses, across a variety of industries. 


\section{Their Impact}

How are hackers, makers and crowdfunding affecting technological innovation, entrepreneurship and the emergence of new industries (Schumpeter 2003)? Together with my colleagues who are doing research on this movement, I see five trends worth noting, and some questions worth raising:

1. User-driven innovation is often a major source of product improvements, as well as totally new products, in established industries (Von Hippel 2005). Usergenerated innovations can launch brand new industries. Studies show this has happened in medical devices, juvenile products, extreme sports gear and typesetting, among other industries. Previously, users were stymied if they wanted to hack existing products or experiment with modifications that required expensive and hard-to use-tools. As the cost of tools such as laser cutters, CNC machines and 3-D printers has dropped and such tools have been added to maker spaces, users have gained access to a much more diverse portfolio of possibilities. Will the rate of user-driven innovation increase as the cost of the new technologies for the maker movement drops and as more people gain access to them (Von Hippel 2005)? From an evolutionary point of view, the number of people involved in generating technological variations is increasing rapidly, creating more opportunities for adaptation and innovation (Van de Ven et al. 1999; Aldrich and Yang 2012).

2. The tools available in maker spaces enable users to experiment with variations on their designs quickly and cheaply. Rapid prototyping, in particular, means that it is now possible for nascent entrepreneurs to invest far fewer resources in the start-up phase of their businesses (Hatch 2013). For example, the founders of Square, an inexpensive Internet-based payment system for small retailers, used the tools and help they received at a local TechShop in California to prototype their system far more cheaply than if they had gone to an engineering and design firm. Will rapid prototyping ultimately decrease the number of business failures and associated losses that result from ill-conceived attempts to start businesses based on poorly designed products or those with no ready market?

3. A hallmark of the maker movement is its grounding in an ideology promoting cooperation and sharing (Lang 2013). To some extent, this ideology is a legacy of the local autonomy and alternative institutions movements of the 1960s and 70s, which promoted localism and community over big corporations and rampant consumerism (Rothschild 1986). Experienced artisans volunteer at maker spaces to help novices, and people are expected to share what they know with others to solve design and fabrication problems. But this emphasis on sharing creates a potential conundrum for the maker movement, because cooperation and innovation, assisted by online platforms, can lead to products with great commercial value. Will new institutions arise to mitigate or negotiate the tensions produced by makers' norms of cooperation versus capitalist economy norms of private appropriation (Thornton, Ribeiro-Soriano and Urbano 2011)? Will maker space-enabled entrepreneurs, pursuing private gains and assisted by online resources, undermine the cooperative norms and values underlying the maker movement?

4. The maker movement depends upon a growing institutional infrastructure of Internet-based sharing, marketing and distribution platforms (Chesbrough 2003). Some of these are managed cooperatively but others are private, for-profit operations -- such as Etsy, which provides a retail market for handicraft-produced goods, or Shapeways, which allows makers to get help with designing and producing their products and then selling them. The growing infrastructure has broadened the reach of small entrepreneurial firms; cloud-based business services, such as GoDaddy, enable small businesses to outsource many operating processes to others (Aldrich and Fortune 2000). The result is potentially revolutionary for entrepreneurship. What are the resource dependence dynamics underlying relations between new maker-entrepreneurs and the emerging, mostly privately held companies that facilitate the maker movement and the commercialization of products generated by it (Wry, Cobb and Aldrich 2013)? Resource dependence theory seems highly appropriate in an examination of relations between thousands of small-scale entrepreneurs and a handful of large international corporations.

5. The emergence of crowdfunding has given nascent entrepreneurs access to resources unavailable through traditional credit markets (Mollick 2014). Asset-based lenders, such as banks and commercial credit companies, are not interested in start-ups with few assets to back up possible loans. Family and friends may be able to provide a small amount of seed capital, but few nascent entrepreneurs can raise enough money 
through that route to scale up their businesses from a simple prototype to one serving a larger market. Angel investors are one possibility, but their method of evaluating new venture proposals may cause them to miss opportunities that a crowdfunding appeal would demonstrate. In contrast, crowdfunding platforms such as Kickstarter, Indiegogo, and FundedByMe - - some donation-based, others equity-based - - give nascent entrepreneurs the potential to raise thousands or tens of thousands of dollars for scaling up their new venture. Will equity-based crowdfunding make of thousands of new businesses possible? What institutional developments might facilitate a smooth transition from the current funding system into a new one? A potentially serious development in this regard is the prospect that early imperfections in the crowdfunding system will lead to large economic losses, potentially damaging the financing prospects for a generation of entrepreneurs to come.

\section{References}

Aldrich, $\mathrm{H}$.

E.

presentation

(http://www.esbri.se/forelasning_tv_visae.asp?id=7585 2334) sponsored by ESBRI, the Center for Research on Small Business \& Entrepreneurship, in Stockholm, Sweden, on September 30, 2013. Note: The presentation link (http://www.esbri.se/forelasning_tv_visae.asp?id=7585 2334) is to a record of a talk I gave at a symposium for the Entrepreneurship and Small Business Research Institute, Stockholm. The occasion was also used to present several awards to outstanding Swedish entrepreneurs. Thus, at the beginning of the video, there are several minutes of explanation, by the master of ceremonies.

Aldrich, H. E. and A. Fortune (2000). Can't Buy Me Love' (But I Know Where You Can Rent It): The Emerging Organizational Community Around Webbased Application Service Providers. Annual Academy of Management Conference, Toronto.

Aldrich, H. E. and T. Yang (2012). "Lost in Translation: Cultural Codes Are Not Blueprints." Strategic Entrepreneurship Journal 6(1): 1-17.

Anderson, C. (2012). Makers: the New Industrial Revolution. New York, Crown Business.

Chesbrough, H. W. (2003). Open Innovation: the New
Imperative for Creating and Profiting from Technology. Boston, Mass., Harvard Business School Press.

Gershenfeld, N. A. (2005). Fab: the Coming Revolution on Your Desktop - from Personal Computers to Personal Fabrication. New York, Basic Books.

Hatch, M. (2013). The Maker Movement Manifesto: Rules for Innovation in the New World of Crafters, Hackers, and Tinkerers. New York, McGraw-Hill.

Lang, D. (2013). Zero to Maker: Learn (Just Enough) to Make (Just about) Anything. New York, Maker media.

Mollick, E. (2014). "The Dynamics of Crowdfunding: an Exploratory Study." Journal of Business Venturing 29(1): $1-16$.

Rothschild, J. (1986). The Cooperative Workplace: Potentials and Dilemmas of Organizational Democracy and Participation. Cambridge, Cambridge University Press.

Schumpeter, J. (2003). Entrepreneur, translated by Markus C. Becker and Thorbjørn Knudsen from J.A. Schumpeter, 1928, "Unternehmer." Handwörterbuch der Staatswissenschaften, 4th ed., Verlag von G. Fischer, Jena, VIII, 476 -- 487. Advances in Austrian Economics. Schumpeter, J., Ed. Amsterdam, The Netherlands, Elsevier. 7.

Thornton, P. H., D. Ribeiro-Soriano and D. Urbano (2011). "Sociocultural Factors and Entrepreneurial Activity: an Overview." International Small Business Journal 29(2): 105-118.

Van de Ven, A. H., D. E. Polley, R. Garud and S. Venkataraman (1999). The Innovation Journey. New York, Oxford University Press.

Von Hippel, E. (2005). Democratizing Innovation. Cambridge, MA, MIT Press.

Wry, T., J. A. Cobb and H. E. Aldrich (2013). "More than a Metaphor: Assessing the Historical Legacy of Resource Dependence and its Contemporary Promise as a Theory of Environmental Complexity." The Academy of Management Annals 7(1): 441-488. 